\title{
The Effect of Argumentation-Based Science Teaching Approach on 8th Graders' Learning in the Subject of Acids-Bases, their Attitudes towards Science Class and Scientific Process Skills
}

\author{
Evrim Ural ${ }^{1 *}$, Durdu Mehmet Gençoğlan ${ }^{1}$
}

${ }^{1}$ Kahramanmaraş Sütçü İmam University, TURKEY

*Corresponding Author: evrimural@gmail.com

***This study is adapted from the Master Thesis of Durdu Mehmet Gençoğlan

Citation: Ural, E., \& Gençoğlan, D. M. (2020). The Effect of Argumentation-Based Science Teaching Approach on 8th Graders’ Learning in the Subject of Acids-Bases, their Attitudes towards Science Class and Scientific Process Skills. Interdisciplinary Journal of Environmental and Science Education, 16(1), e02207. https://doi.org/10.29333/ijese/6369

\section{ARTICLE INFO}

Received: 28 Oct. 2019

Revised: 24 Nov. 2019

Accepted: 1 Dec. 2019

\begin{abstract}
Studies show that there are difficulties in learning the subject of acids and bases. For this reason, in the scope of the study, case studies which use daily life context are used to help students to establish the relation between acid-bases and daily life. In the content of the study, it was aimed to provide hands-on learning opportunities with performing experiments in the laboratory. It was thought that argument based science learning supported with authentic case studies would facilitate the students to learn the concepts of acid and base and support the development of their scientific process skills. The study aimed to investigate the effect of argumentation-based science teaching approach on 8th graders' learning of the subject of acids and bases, their attitudes towards science class and their scientific process skills. The sample of the study consisted of 698 th grade students from two different classes attending Science and Technology Course at a government school. The quasi-experimental research design which is one of the quantitative research designs was used in the content of the study. The experimental group was taught through Argumentation Based Science Learning Approach and the control group was taught through didactic teaching approach. The academic achievement test for the subject of acids and bases, Science Class Attitude Scale and Science Process Skills test were administered as pre-test prior to the application and post test following to the application. The results revealed that the argumentation based science teaching approach was more effective than the didactic teaching approach while learning the subject of acids and bases. The findings displayed that the academic achievement of the students taught with argumentation based approach was higher than the ones taught with didactic teaching approach. The findings of the study displayed that the Argumentation Based Science Learning Effect had no significant effect on students' attitudes towards science class. But the approach had a significant effect on students' science process skills.
\end{abstract}

Keywords: learning acid-bases, argumentation based science learning, science process skills, science class attitude

\section{INTRODUCTION}

Although the educators have now understood that meaningful learning occurs with the structuring of knowledge in students' minds, instructors present scientific concepts and facts to the students, and they are still expected to memorize these concepts and facts. However, this leads students to see science as a process that consists of a series of concepts to be memorized and to develop an unreal perception of science. In this way, students have no idea of how scientists develop scientific knowledge, and at the same time, they cannot develop scientific process skills. Driver, Newton, and Osborne (2000) stated that while learning scientific concepts, students should also learn their epistemology, the practices, and methods of science, and its' nature. Today the aim of science education programs is not just learning knowledge, but also it aims to develop students' abilities to understand the epistemology of the knowledge (how we know, etc.) (JimenezAleixandre, Rodriguez, \& Duschl, 2000). While learning scientific concepts, it is important for students to understand how scientists develop scientific knowledge and to be aware of the working processes of a scientist. Science is a process of social construction of knowledge and seeing the world with different perspectives (Driver, Newton, \& Osborne, 2000). For this reason, just giving scientific facts to the students is not enough for developing understanding different perspectives. 
Nowadays, science instructors have understood that students need a scientific inquiry for meaningful learning in science education. In scientific inquiry, students need to make decisions, think about their judgments and use claims and data just like scientists. For effectivescience education, students should discover the power and the limitation of scientific knowledge claims. Additionally, students confront with various scientific claims in their daily lives. Students should understand the knowledge underlying the claims they confronted and develop reasoning abilities for evaluating these claims and create their arguments. Therefore, science education focuses on providing opportunities for students to develop their critical thinking about scientific concepts and develop clear and valid explanations, use supportive evidence for their claims.

Science learning is constructing and using tools while generating knowledge about the natural world (Erduran, Simon, \& Osborne, 2004) and according to this definition, argumentation can be an effective tool while constructing scientific knowledge. Argumentation plays an important role in science education since with the heuristic approach students can reach conceptual and epistemic goals, and the argumentation process can foster students' scientific thinking and reasoning in the process (Osborne, Erduran, \& Simon, 2004). The science education aims to develop students' ability to access the world with multi-perspectives, and this is possible only by evaluating the multiple reasons of the scientific phenomena and various data in the argumentation process. There are some studies in the literature which focus on argumentation approach in science education (Driver, Newton, \& Osborne, 2000; Duschl \& Osborne, 2002; Zohar \& Nemet, 2002). These studies summarized the requirement of argumentation process in science education as below (Von Aufschnaiter, Erduran, Osborne, \&Simon, 2008; Newton, Driver, \& Osborne, 1999):

1. While developing scientific knowledge, scientists follow the scientific research process and construct arguments for explaining the phenomenon, try to get evidence to support their arguments.

2. The individuals confront scientific debates in their daily lives and need to make decisions about these debates. Generally, their decision is based on the information they get via media resources. However, to make the right decisions within the information pollution caused by the unlimited internet resources, they should be able to evaluate the evidence from different sources and to create scientific arguments.

3. To emerge conceptual understanding, students should realize the relation between the cause and effect relationships; express their doubts and present alternatives. The argumentation process can help to attain this goal.

Science education does not just aim in learning scientific concepts. It also aims to develop students' scientific inquiry abilities. Scientific inquiry is generating claims and justifying these claims (Jimenez-Aleixandre, Rodriguez, \& Duschl, 2000). This is possible with the argumentation process because the argumentation theory is to develop strategies to solve problems, events, and controversial situations. Driver, Newton, and Osborne (2000) stated the role of argumentation in science education as learning science does not just know what a phenomenon is, and it also knows the relation of this phenomena with other phenomena and the importance of the phenomena and argumentation is an understanding process of this.

There are various definitions of arguments in the literature. For example, Suppe (1998) identifies argumentation as the coordination of evidence and theory to prove or disprove an idea. According to Toulmin (1958), an argument is introducing a claim and justifying this claim (Zohar \& Nemet, 2002). Toulmin (1958) proposed a model to evaluate the argumentation process, and this model has been used in many domains such as legal settings and science education (Cross, Taasoobshirazi, Hendricks, \& Hickey, 2008; Driver, Newton, \& Osborne, 2000). Toulmin (1958) described the elements of argument as claims, data, warrants, backings, qualifiers, and rebuttals (Von Aufschnaiter, Erduran, Osborne, \& Simon, 2008). Scientists use arguments to connect the evidence with the claims the proposed trough the warrants and backings (Erduran, Simon, \& Osborne, 2004). For this reason, while forming scientific explanations, the argumentation process plays an important role. Cross, Taasoobshirazi, Hendricks, and Hickey (2008) and Driver, Newton, and Osborne (2000) explained the main components of Toulmin's model as below:

(a) The claim is a conclusion, a hypothesis, or an idea.

(b) Data are the facts which the claim.

(c) The warrant is a bridge between the data and the claim. It explains how the data supports the claim. The warrant explains the reasons (rules, principles, etc.).

(d) The backing is an assumption which is used to help to justify warrants;

(e) Rebuttal provides evidence to disprove the presented other claims, or it displays the conditions when the claim will not be true.

(f) Qualifier displays the limitation of the claims; it shows under which conditions the claim can be accepted as true.

Figure 1 displays Toulmin's Argumentation Pattern with an example related to the subject of acids and bases.

In the literature, there are some studies which search for the effect of the argumentation process on students' conceptual learning in science education. For example, Zohar and Nemet (2002) examined the teaching of argumentation skills of students through dilemmas in the subject of human genetics. They stated that before the application only a minority of the students could construct arguments by using correct biological knowledge. Most of the students could construct simple arguments. Following the application, through using dilemmas in the argumentation process, the findings revealed that there was an increase in the number and the quality of the arguments that students constructed. Additionally, Jime'nez-Aleixandre, Bugallo, and Duschl, (2000), Jime'nez-Aleixandre and Pereiro-Munhoz, (2002), Leach (1999), and Mason (1996), in their studies displayed that students' conceptual understanding increased when they were taught by argumentation approach. In some studies (Kelly, Drucker, \& Chen, 1998; Osborne, Erduran, \& Simon, 2004; Zohar \& Nemet, 2002), the researchers also displayed that the quality of students' arguments and the number of students' arguments increased through the argumentation approach. Osborne, Erduran, and Simon (2004) stated when students' interaction and discourse supported, the quality of the 


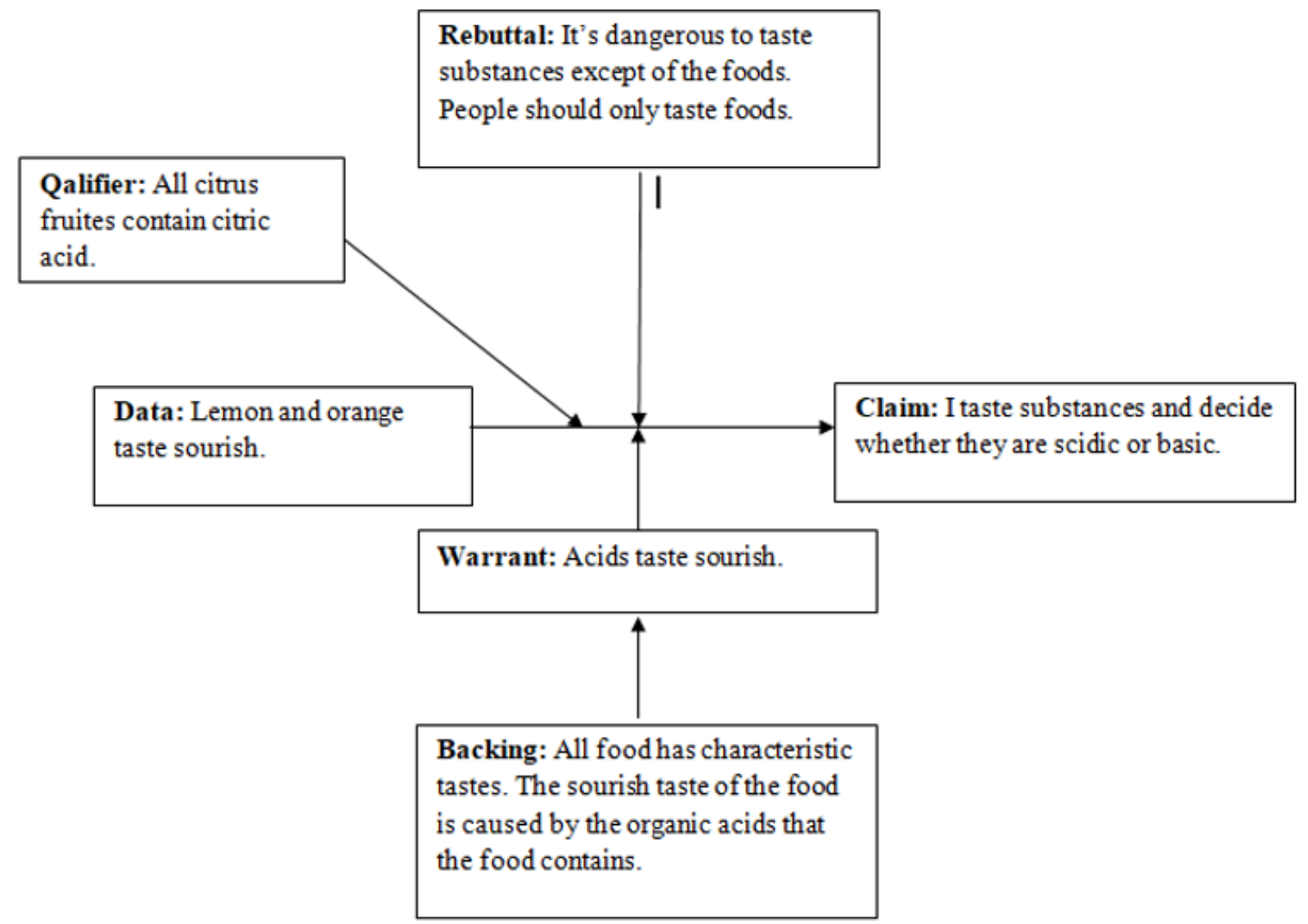

Figure 1. Toulmin's Argumentation Pattern with an example related to the subject of acids and bases

argumentation process increased. Furthermore, argumentation process encourages student-student and student-teacher discourse (Jime'nez-Aleixandre, Bugallo, \& Duschl, 2000; Kelly, Drucker, \& Chen, 1998; Osborne, Erduran, \& Simon, 2004; Schwarz, Neumann, Gil, \& Ilya, 2003; Zohar \& Nemet, 2002). In this process, students are learning scientific concepts but also they learn to develop arguments (Erduran, Simon, \& Osborne, 2004; Jime'nez-Aleixandre \& PereiroMunhoz, 2002; Schwarz, Neumann, Gil, \& Ilya, 2003). By using argumentation approach in science learning, the researchers noticed the importance of the discourse in learning (Driver, Asoko, Leach, Mortimer \& Scott, 1994; Newton, Driver, \& Osborne, 1999; Nussbaum \& Sinatra, 2003). In argumentation process students, propose ideas, try to support their ideas about scientific phenomena, and by this way, they use scientific theories, pieces of evidence to support their claims and disprove the others claims (Von Aufschnaiter, Erduran, Osborne, \& Simon, 2008).

Argument based science learning promotes students' scientific literacy since the approach provides hands 'on learning activities and fosters students' communication skills with others (Akkus, Gunel, \& Hand, 2007; Demirbağ \& Günel, 2014). Keys (2000) and Yore (2000) stated that argument based science learning enhances critical thinking, reasoning, writing, andhigher-order cognitive skills and also develops students' understanding of the nature of science.

The researchers stated that students learn better when they discussed different ideas and expressed their ideas (Cross, Taasoobshirazi, Hendricks, \& Hickey, 2008). Patronis, Patori, and Spiliotopoulou (1999) stated that by this way students realize that science is constructed through ideas, the scientists question these ideas, changed and revised them, and science is a developing and continuous process. In the argumentation process, students participate in a process similar to the scientists, and by this way, they evaluate claims, ideas, and data.

As can be seen from the information given above, the argumentation approach is an effective approach for students to learn scientific concepts and develop some skills. Students might have some difficulties while learning the concepts in science classes because of the abstract character of these concepts. While learning abstract concepts, it is important to create a learning environment where students can think, search and ask questions like a scientist. There are many scientific concepts in science education that students have difficulty while learning.

One of these concepts is the concept of acid-base. The subject of acid-base is considered to be difficult by many students. The concept of acids and bases plays important roles in biological activities and also in our daily lives. Additionally, the subject of acids and bases is very important while learning chemistry, since most of the reactions are acid-base reactions (Çetingül \& Geban, 2005). Therefore, the subject of acids and bases is very important in the chemistry curriculums at all stages of education (Kala, Yaman, \& Ayas, 2013). In Turkey, the subject of acid-base is being taught at 8th grade for the first time. But, the concepts in the subject cannot be learned easily. Since there are many abstract concepts in chemistry, students have difficulties while learning the concepts in chemistry class (Demircioğlu, Özmen, \& Ayas, 2004). Various studies in the 
Table 1. Research design and information about sampling, teaching approach,and data collection tools

\begin{tabular}{|c|c|c|c|c|}
\hline Groups & Number of Students & Pre-Tests & Teaching Approach & $\begin{array}{c}\text { Post-Tests } \\
\end{array}$ \\
\hline $\begin{array}{l}\text { Experimental } \\
\text { Group } \\
\text { (EG) }\end{array}$ & 34 & $\begin{array}{l}\text { Acid-Base Achievement Test } \\
\text { Scientific Process Skills Test } \\
\text { Science Class Attitude Scale }\end{array}$ & $\begin{array}{c}\text { Argumentation-Based } \\
\text { Science Teaching } \\
\text { Approach }\end{array}$ & $\begin{array}{l}\text { Acid-Base Achievement Test } \\
\text { Scientific Process Skills Test } \\
\text { Science Class Attitude Scale }\end{array}$ \\
\hline $\begin{array}{l}\text { Control Group } \\
\text { (CG) }\end{array}$ & 35 & $\begin{array}{l}\text { Acid-Base Achievement Test } \\
\text { Scientific Process Skills Test } \\
\text { Science Class Attitude Scale }\end{array}$ & $\begin{array}{l}\text {-Didactic teaching } \\
\text {-Question-answer } \\
\text { technique }\end{array}$ & $\begin{array}{l}\text { Acid-Base Achievement Test } \\
\text { Scientific Process Skills Test } \\
\text { Science Class Attitude Scale }\end{array}$ \\
\hline
\end{tabular}

literature reveal the learning difficulties and misconceptions of students at different levels of education (Kousathana, Demerouti, \& Tsaparlis, 2005; Tarhan \& Acar Sesen, 2012). For example, Kala, Yaman, and Ayas (2013) searched for high school students' understandings of some concepts in acids and bases subjects such as regarding $\mathrm{pH}, \mathrm{pOH}$, microscopic level, strength, and concentration. Their findings revealed that students had difficulties while determining the strength of the acids and some of the students had misconceptions related to pH and pOH. Demircioğlu, Ayas and Demircioğlu (2005) state that learning acid-based concepts is difficult at the high school level,and some common alternative conceptions are determined for topics like $\mathrm{pH}$, conjugate acid-base pairs, salts, neutralization, titration, and buffer (Demircioğlu, Ayas, \& Demircioğlu, 2005; Sheppard 2006; Schmidt 1995). Ross and Munby (1991) searched for senior high school student's understanding of the acid-base concept and displayed that they have many misconceptions related to these concepts. Artdej, Ratanaroutai, Coll, and Thongpanchang (2010) searched for Grade 11 students' alternative conceptions for acid-base chemistry and revealed that most of the students had many misconceptions related to acid-base theory, dissociation of strong acids or bases, and dissociation of weak acids/bases. Karadeniz Bayrak (2013) searched for primary students' conceptual understanding and alternative conceptions in the subject of acid-base and found that students dad difficulties while learning the concepts in the subject and has some misconception related to the subject. Even pre-service teachers have misconceptions about acids and bases (Bradley \& Mosimege, 1998).

Studies show that there are difficulties in learning the subject of acids and bases. The instructors should use studentcentered methods instead of traditional teaching methods to facilitate students' learning. When students ask questions, share their ideas and get immediate feedback, they construct knowledge more effectively (Cross, Taasoobshirazi, Hendricks, \& Hickey, 2008). In this context, the activities that will attract students' interests and enable them to relate to daily life would be effective. Aikenhead (2001) stated the positive effect of authentic problem situations on students' knowledgeconstruction.

For this reason, in the scope of the study, case studies which use daily life context are used to help students to establish the relation between acid-bases and daily life. In this way, it is aimed to increase the interest of students and to facilitate their learning. During the argumentation process, students are expected to Express search, think, express their thoughts, and present their claims. In the content of the study, it was aimed to provide hands-on learning opportunities with performing experiments in the laboratory. It was thought that argument based science learning supported with authentic case studies would facilitate the students to learn the concepts of acid and base and support the development of their scientific process skills.

\section{THE AIM OF THE STUDY}

The study aimed to investigate the effect of argumentation-based science teaching approach on 8th graders' learning of the subject of acids and bases, their attitudes towards science class and their scientific process skills. By this aim, the following research questions were prepared:

1. Does the argumentation-based science teaching approach make significant differences in students' academic achievement in the subject of acids and bases?

2. Does the argumentation-based science teaching approach make significant differences in students' attitudes towards science class?

3. Does the argumentation-based science teaching approach make significant differences in students' scientific process skills?

\section{METHOD}

\section{Samples}

The sample of the study consisted of 69 8th grade students from two different classes attending Science and Technology Course at a government school in Kahramanmaraş/Turkey. The sample was selected by incidental sampling method.

\section{Research Design}

The quasi-experimental research design which was one of the quantitative research designswas used in the content of the study. The information about the experimental and control groups, teaching approach and data collection tools is given in Table 1.

The application process was completed in 7 weeks $\left(1^{\text {st }}\right.$ week: Administering pre-tests, $2^{\text {nd }}$ week: Giving information about Toulmin's argumentation model and argumentation based science learning, $3^{\text {rd }}, 4^{\text {th }}, 5^{\text {th }}$ and $6^{\text {th }}$ weeks: Argumentation-based science learning activities, $7^{\text {th }}$ week: Administering post-tests. 


\section{DATA COLLECTION TOOLS}

In the content of the study to attain the aim of the study, the data was collected through administering Acid-Base Achievement Test, Science Class Attitude Scale andthe Scientific Process Skills Test.

\section{Acid-Base Achievement Test}

Acid-Base Achievement Test (AAT) was prepared by Doğan and Gökçek (2006) through the objectives of the subject of acids and bases for evaluating students' achievement in the subject. The Cronbach Alpha reliability coefficient of the test was calculated as 0.87 . Thetest consisted of 20 multiple choice items, and each correct answer was given 1 point, whereas incorrect ones received 0 points, and the highest point that can get is 20 (Kılınç, 2014). Some examples of the items are given below:

\section{Example-1.}

I. Their aqueous solutions are electrically conductive.

II. Releasing positive hydrogen $\left(\mathrm{H}^{+}\right)$ions

III. Reacting with metals

IV. Turning litmus paper's color.

Which of the properties is not a common feature of acids and bases?
a) I-II
b) II-III
c) I-III
d) II-IV

Example-2. Which of the following statements is wrong for strong acids?

a) Turn blue litmus paper red.

b) React with metals and the reaction produces $\mathrm{H}_{2}$ gas.

c) Their aqueous solutions are electrolyte.

d) Releasing negative hydroxide $\left(\mathrm{OH}^{-}\right)$ions.

\section{Science Class Attitude Scale}

Science Class Attitude Scale (SCAS) was developedby Şaşmaz-Ören (2005), and it was a 5-point Likert type scale. The scale was composed of 22 items. Thirteen of the items were a positive statement, and 9 of the items were negative statements. Positive statements were coded as "completely agree $=5$, agree $=4$, undecided $=3$, disagree $=2$, completely disagree=1" (Meriç, 2014). Negative statements were coded in reverse. The Cronbach Alpha Reliability Coefficient was calculated as 0.925 . Some examples of the items were given below:

Example-1. I like reading books about science.

Example-2. I don't like science class and to have to study science.

\section{Scientific Process Skills Test}

Scientific Process Skills Test was originally developed by Okey, Kevin (1985) and adapted to Turkish by Özkan, Aşkar and Geban (1992) and Aydoğdu, Yıldız, Akpınar and Ergin (2006) was reformed the test. The latest version of the test consisted of 25 multiple choice items. The Cronbach Alpha reliability of the test was 0.81 . In the test, there were questions about defining variables, operational identification, hypothesis setting, providing operational explanations, designing necessary investigations for problem-solving, drawing graphics and interpreting the data.

Example-1. A car manufacturer wants to make more economical cars. Researchers are investigating variables that can influence the distance that the car can take per liter. According to you, which of the following variables may affect the distance that the car can take per liter?
a. The weight of the car
b. The size of the engine
c. The color of the car
d. $a$ and $b$.

Example-2. A police chief is dealing with reducing the speed of cars. He thinks that some factors can affect the speed of cars. If you were the police chief, which of the following hypotheses would you test how fast the drivers drive?

a. Younger drivers are more likely to drive faster.

b. When the cars are bigger, the possibility of the insurance of their passengers decreases.

c. The more police teams are on the roads, the number of accidents are decreased.

d. The possibility of an accident increases when the cars get older,

\section{APPLICATION}

\section{The Teaching Process in the Experimental Group}

The science class was held 4 hours a week. Before the application, the instructor informed experimental group students about the Argumentation Based Science Teaching Approach. The teacher explained the steps of the application process and the expectations to the students.

\section{The Preparation Process}

\section{Writing an authentic scenario}

An authentic scenario consisting of 3 chapters was prepared to enable the students to learn the concepts in the subject of acids and bases, and the scenario was prepared considering students' daily lives. The prepared authentic scenario was checked by two science education specialists and a chemistry education specialist. The study was conducted in a rural school (in a village). The scenario mentioned about a boy called Mustafa (a common name in Turkey) and the events were related to daily life in a village that Mustafa could encounter. The researchers aimed to mention the concepts in the subject of acid-bases in the scenario. The following table presents the learning gains covered by the authentic scenario. 
Table 2. Distribution of the learning gains according to the sections of authentic scenario

\begin{tabular}{l}
\hline The learning gains embedded in the authentic scenario \\
\hline Section 1 \\
\hline 1. S/he recognizes acids and bases with the touch, taste and visual senses. \\
2. S/he establishes a relationship between the bases and $\mathrm{OH}$-ion and the acids and $\mathrm{H}^{+}$ion. \\
3. S/he understands that $\mathrm{pH}$ is a measure of how acidic or how basic a solution is, and establishes a relationship between acidity- \\
basicity and pH scale \\
4. S/he knows the main acids and bases used in industry and recognizes their systematic names and formulas. \\
5. S/he recognizes the names of most common acids and bases used in foods and cleaning materials. \\
6. He knows the approximate pH of some of the products that s/he frequently encounters in daily life.
\end{tabular}

\section{Section 2}

7. S/he displays the interaction of bases and bases by experimenting; s/he calls this interaction as a neutralization reaction and states the products of this reaction.

8. S/he explains why s/he should be careful while using acid-base solutions; expresses the meanings of hazard signs for chemicals.

9. $\mathrm{S} /$ he explains what $\mathrm{s} /$ he could do to avoid the negative effects of acids and bases on the materials in daily life.

\section{Section 3}

10. $\mathrm{S} /$ he understands that the industry releases $\mathrm{SO}_{2}$ and $\mathrm{NO}_{2}$ gases as wastes into the air and these gases cause acid rain and they have negative effects on the environment.

11. $\mathrm{S} /$ he develops awareness to the chemical which pollutes water, air,and soil.

The title of the experiment:
Research question:
What did I do to find an answer to the research question?
Claim:
Data:
Warrant:
Backing:
Rebuttal:
My argument:

Figure 2. Science Laboratory Experiment Form

Students were requested to answer the questions in the worksheets and filled the Science Laboratory Experiments Forms. The first part of the authentic scenario is displayed in Appendix 1.

\section{Preparing worksheets}

Worksheets were prepared about the authentic scenarios. The mentioned worksheets included questions prepared about the events in the authentic scenarios. The aim of these questions was to foster the students to search for the concepts in the authentic scenarios.

The mentioned worksheets were prepared, and final arrangements were conducted through the views of one science education expert or and two chemistry education experts. One worksheet was prepared for each part of the authentic scenario. The worksheet prepared for the first part of the authentic scenario is displayed in Appendix 2.

\section{Preparing Science Laboratory Experiment Form}

In addition to the literature review, students conducted experiments and observations to reach the desired learning gains. A science laboratory experiment form was prepared for students. In the laboratory, they wrote down the obtained results and their arguments. In the science laboratory experiment form, the research question, what I did to find an answer to the research question, the claim, the data, the warrant, the backings, the rebuttal, and the scientific argument parts are included. The science laboratory experiment form was prepared according to the Toulmin's Argumentation Model, and they were prepared for students to express their scientific arguments. A total of four experiments were carried out within the scope of the application. The titles of the experiments are given below:

Experiment 1: How do we distinguish between acids and bases encountered in daily life?

Experiment 2: Neutralization reactions

Experiment 3: Acid rains and their effects on the environment

Experiment 4: Effects of acids and bases on human body and materials.

Students filled the Science Laboratory Experiment Form following to the each of the experiments. The science Laboratory Experiment Form is displayed in Figure 2. 
Table 3. Comparison of the pre-test scores of the groups with independent samples t-test

\begin{tabular}{|c|c|c|c|c|c|c|}
\hline Pre-Test & Groups & $\mathbf{N}$ & $\mathbf{M}$ & SD & $t$ & $\mathbf{p}$ \\
\hline \multirow{2}{*}{ AAT } & Group 1 & 34 & 5.176 & 2.46 & \multirow{2}{*}{-0.502} & \multirow{2}{*}{0.618} \\
\hline & Group 2 & 35 & 5.457 & 2.19 & & \\
\hline \multirow{2}{*}{ SCAS } & Group 1 & 34 & 85.500 & 12.39 & \multirow{2}{*}{-0.899} & \multirow{2}{*}{0.372} \\
\hline & Group 2 & 35 & 88.028 & 10.94 & & \\
\hline \multirow{2}{*}{ SPST } & Group 1 & 34 & 36.588 & 13.55 & \multirow{2}{*}{-0.554} & \multirow{2}{*}{0.581} \\
\hline & Group 2 & 35 & 39.114 & 14.68 & & \\
\hline
\end{tabular}

Table 4. Comparison of post-test scores of experimental and control groups with independent samples t-test

\begin{tabular}{|c|c|c|c|c|c|c|}
\hline Post-Test & Groups & $\mathbf{N}$ & $\mathbf{M}$ & SD & $t$ & p \\
\hline \multirow{2}{*}{ AAT } & EG & 34 & 9.529 & 2.286 & \multirow{2}{*}{2.741} & \multirow{2}{*}{0.008} \\
\hline & CG & 35 & 7.914 & 2.593 & & \\
\hline \multirow{2}{*}{ SCAS } & EG & 34 & 87.823 & 14.608 & \multirow{2}{*}{-0.493} & \multirow{2}{*}{0.623} \\
\hline & CG & 35 & 89.457 & 12.871 & & \\
\hline \multirow{2}{*}{ SPST } & EG & 34 & 43.764 & 12.453 & \multirow{2}{*}{0.883} & \multirow{2}{*}{0.380} \\
\hline & CG & 35 & 40.828 & 15.006 & & \\
\hline
\end{tabular}

*EG: Experimental Group; CG: Control Group

\section{The weekly plan of the application process}

The science class was hold 4 hours a week.

The first two hours: Students were asked to read the sections of the authentic scenario and requested to think about the concepts in the scenario. Then, the teacher handed the worksheet prepared about the section out to the students. The students were requested to answer the questions in the worksheets. The teacher brought the resources that students would need while searching the answers to these questions. The students read the case studies and searched for the answers to the questions. Then, the answers to the questions were discussed among the students.

Last two hours: An experiment was designed in a laboratory environment for students every week. Before the experiment, the students filled "The research question," "What did I do to find an answer to the research question?" and "The Claim" parts in the Science Laboratory Experiment Form. Following the experiment, they filled out the data, warrant, backing, rebuttal and my argument parts.

\section{The Teaching Process in the Experimental Group}

Within the scope of the study, the students in the control group was taught through didactic teaching approach. In other words, the teacher actively took part in the teaching process. The teacher used didactic teaching method and questionanswer technique. The students used the course book and followed the activities suggested in the course book. In the control group, the teacher followed the annual schedule. At the beginning of the course, the teacher summarized the previous lecture, and at the end of the lecture, the teachers posed questions related to the learning gains of the day to the students.

\section{FINDINGS}

The data, obtained from the pre-post test results of the experimental and control group were analyzed, and the following findings were obtained. The quantitative data obtained within the scope of the study showed normal distribution and the required statistical analyzes were made accordingly.

\section{The Comparison of Experimental and Control Groups' Pre-test Scores}

The students participated in the study were attending two different classes. One of the classes called Group 1 and the other one was called as Group 2 at the beginning of the study. The data collection tools (AAT, SCAS, and SPST) were administered to the students' of Group 1 and Group 2 as pretest before the application. The pre-test scores of Group 1 and Group 2 students were compared with the help of independent samples t-test to determine whether there was a difference between the pre-test scores of the groups. The findings of independent samples t-test were displayed in Table 2 .

The findings displayed that there was no significant difference between the pre-test AAT scores of Group 1 and Group 2 students $(t=-0,502 ; p=0,618>0,05)$; there was no significant difference between the pre-test SCAS scores of Group 1 and Group 2 students ( $t=-0,899 ; p=0,372>0,05)$; there was no significant difference between the pre-test SPST scores of Group 1 and Group 2 students ( $t=-0,554 ; \mathrm{p}=0,581>0,05)$. The comparison of the pre-test scores displayed that the groups displayed similar characteristics and Group 1 was attended as the experimental group (EG), and the Group 2 was attended as the control group (CG) randomly.

\section{The Comparison of Experimental and Control Groups' Post-test Scores}

Following the study, AAT, SCAS, and SPST were administered to the experimental and control groups. Experimental and control group students' post-test AAT, SCAS and SPST scores were compared with independent samples t-test, and the results were displayed in Table 4.

Independent samples t-test results displayed that post-test AAT scores of the experimental group ( $M=9.52)$ were higher than those of the control group $(M=7.91)$ and that the difference was significant $(\mathrm{t}=2.741 ; \mathrm{p}=0.008<0.05)$. No meaningful differences were detected between the post-test 
Table 5. Comparison of pre and post-test scores of the control group students with paired samples t-test

\begin{tabular}{|c|c|c|c|c|c|c|}
\hline Test & & $\mathbf{N}$ & $\mathbf{M}$ & SD & $\mathbf{t}$ & $\mathbf{p}$ \\
\hline \multirow{2}{*}{ AAT } & Pre-test & 35 & 5.457 & 2.187 & \multirow{2}{*}{-4.501} & \multirow{2}{*}{0.000} \\
\hline & Post-test & 35 & 7.914 & 2.593 & & \\
\hline \multirow{2}{*}{ SCAS } & Pre-test & 35 & 88.028 & 10.942 & \multirow{2}{*}{-1.152} & \multirow{2}{*}{0.257} \\
\hline & Post-test & 35 & 89.457 & 12.871 & & \\
\hline \multirow{2}{*}{ SPST } & Pre-test & 35 & 39.114 & 14.678 & \multirow{2}{*}{-0.865} & \multirow{2}{*}{0.393} \\
\hline & Post-test & 35 & 40.8286 & 15.00683 & & \\
\hline
\end{tabular}

Table 6. Comparison of pre and post-test scores of the experimental group students with paired samples t-test

\begin{tabular}{|c|c|c|c|c|c|c|}
\hline Test & & $\mathbf{N}$ & $\mathbf{M}$ & SD & $t$ & p \\
\hline \multirow{2}{*}{ AAT } & Pre-test & 34 & 5.176 & 2.455 & \multirow{2}{*}{-12.161} & \multirow{2}{*}{0.000} \\
\hline & Post-Test & 34 & 9.529 & 2.286 & & \\
\hline \multirow{2}{*}{ SCAS } & Pre-Test & 34 & 85.500 & 12.385 & \multirow{2}{*}{-1.298} & \multirow{2}{*}{0.203} \\
\hline & Post-Test & 34 & 87.823 & 14.608 & & \\
\hline \multirow{2}{*}{ SPST } & Pre-Test & 34 & 36.588 & 13.826 & \multirow{2}{*}{-4.788} & \multirow{2}{*}{0.000} \\
\hline & Post-Test & 34 & 43.764 & 12.453 & & \\
\hline
\end{tabular}

Table 7. ANCOVA analysis results when pre-test scores were controlled*

\begin{tabular}{|c|c|c|c|c|c|}
\hline Source of Data & Mean Square & df & $\mathbf{F}$ & $\mathbf{p}$ & Partial Eta Squared \\
\hline Model & 41.86 & 4 & 9.61 & 0.000 & 0.375 \\
\hline AATPre-Test" ${ }^{* * *}$ & 19.30 & 1 & 4.43 & 0.039 & 0.065 \\
\hline SCASPost-Test ${ }^{* * *}$ & 24.23 & 1 & 5.56 & 0.021 & 0.080 \\
\hline SPST Post-Test ${ }^{* * * *}$ & 34.92 & 1 & 8.02 & 0.006 & 0.111 \\
\hline Group & 42.67 & 1 & 9.8 & 0.003 & 0.133 \\
\hline Error & 4.36 & 64 & & & \\
\hline
\end{tabular}

${ }^{*} \mathrm{R}^{2}=0.375^{* * *}$ Controlled variables

SCAS mean scores of the experimental group $(\mathrm{M}=87.82)$ and the post-test SCAS mean scores of the control group ( $\mathrm{M}=89.45$, $\mathrm{t}=-0.493 ; \mathrm{p}=0.623>0.05)$. Similarly, no meaningful differences were detected between the post-test SPST mean scores of the experimental group $(\mathrm{M}=43.76)$ and the post-test SPST mean scores of the control group $(\mathrm{M}=40.82),(\mathrm{t}=0.883 ; \mathrm{p}=0.380>0.05)$.

The Comparison of Control Group Students' Pre-test and Post-test Scores

Paired-samples t-test was carried out to identify whether there were significant differences among the AAT, SCAS and SPST pre and post-test scores of the control group and the findings were displayed in Table 5 .

Table 5 displayed that when control group students' pre and post-test AAT scores were compared, there was a significant increase in favor of the post-test $(t=-4.501$; $\mathrm{p}=0.000<0.05$ ).

When the control group students' pre and post-test SCAS scores were compared, there is no significant difference between pre and post-test SCAS scores $(t=-1.152$; $\mathrm{p}=0.257>0.05$ ).

Similarly, when control group students' pre and post-test SPST scores were compared, there is no significant difference between pre and post-test SPST scores $(\mathrm{t}=-0.865$; $\mathrm{p}=0.393>0.05)$.

\section{The Comparison of Experimental Group Students' Pre-} test and Post-test Scores

Paired-samples t-test was carried out to identify whether there were significant differences among the AAT, SCAS and
SPST pre and post-test scores of the experimental group students and the findings were displayed in Table 6.

Table 6 displayed that when experimental group students' pre and post-test AAT scores were compared, there was a significant increase in favor of the post-test $(t=-12.161$; $\mathrm{p}=0.000<0.05$ ). When experimental group students' pre and post-test SCAS scores were compared, there is no significant difference between pre and post-test SCAS scores $(t=-1.298$; $p=0.203>0.05$ ). When experimental group students' pre and post-test SPST scores were compared, there was a significant increase in favor of the post-test $(t=-4.788 ; \mathrm{p}=0.000<0.05)$.

Covariance analysis (ANCOVA) was implemented on data to determine whether statistically meaningful differences existed between experimental and control groups' post-test AAT scores when the pre-test AAT, SCAS, and SPST scores were controlled. Findings are displayed in Table 7.

According to Table 7, the implemented model is meaningful $(p=0,00)$ and the model explains 37.5 of the academic achievement $\left(\mathrm{R}^{2}=0.375\right)$. The results of ANCOVA analysis display that argumentation-based science teaching approach had a meaningful effect on the experimental group students' academic achievement when the pre-test scores of the groups were controlled.

\section{RESULTS}

In the content of the study, experimental group students were taught the subject of acids and bases through argumentation-based science teaching approach whereas control group students were taught the same subject through 
didactic teaching approach. At the end of the teaching process, experimental and control group students' academic achievement, their attitudes towards science class and scientific process skills were compared. Before the application, the AAT, SCAS, and SPST were administered to both groups as pre-test. Independent samples t-test was implemented to determine whether statistically meaningful differences existed between experimental and control group students' pre-test scores. The paired samples t-test results displayed that there were no significant differences between pre-test AAT, SCAS and SPST scores of the groups ( $p>0.05)$. According to this result, one of the groups was attended as an experimental group, and another one was attended as control group randomly.

Following to the argumentation based teaching activities, AAT, SCAS, and SPST were administered as post-test. Pre-test and post test AAT scores of the experimental group students' were compared through paired samples t-test. The results of the paired-samples t-test displayed that there was a significant increase in favor of the AAT post-test scores. Also when the pre and post-test AAT scores of the control group students were compared through paired sample t-test, the results displayed that there was a significant increase in favor of the post-test AAT scores. Independent samples t-test was implemented to determine whether there was a meaningful difference between experimental group's and control group's post-test AAT scores and the results displayed that there was a significant difference in favor of the post-test AAT scores of the experimental group. This result revealed that the argumentationbased science teaching approach was more effective than the didactic teaching approach while learning the subject of acids and bases.

Pre-test and post-test SPST scores of the experimental group students' were compared through paired samples t-test. The results of paired-samples t-test displayed that there was a significant increase in favor of the SPST post-test scores. When the pre and post-test AAT scores of the control group students were compared through paired sample t-test, the results displayed that there was no significant difference between pre and post-test SPST scores of the control group students.

Independent samples t-test was implemented to determine whether there was a meaningful difference between experimental group's and control group's post-test SPST scores and the results displayed that there was no meaningful difference between experimental and control group post-test SPST scores.

Pre-test and post-test SCAS scores of the experimental group students' were compared through paired samples t-test. The results of paired-samples t-test displayed that there was no significant difference between pre and post-test scores. Similarly, when the pre and post-test SCAS scores of the control group students were compared through paired sample t-test, the results displayed that there was no significant difference between pre and post-test scores.

Independent samples t-test was implemented to determine whether there was a meaningful difference between experimental group's and control group's post-test SCAS scores and the results displayed that there was no significant difference between experimental and control groups' post-test scores. This result revealed that the argumentation based science teaching approach had no significant effect on students' attitude towards science class.

\section{DISCUSSION}

The findings of the study revealed that the academic achievement of the experimental group students who were taught the subject of acids-bases through argumentation based science teaching approach was higher in comparison to the achievement of control group students who were taught the same subject through didactic teaching approach. Similarly, Tuysuz, Demirel and Yildirim (2013) searched for the effect of argumentation, problem, and laboratory-based learning methods on the pre-service teachers' achievement in the subject of acid and base. They stated that the argumentation process helped pre-service teachers to learn the concepts more effectively. Additionally, Karpudewan, Roth, and Sinniah (2016) displayed that, green chemistry activities requiring argumentation lead to better understanding of the subject of acid-base. There are various studies investigated the effect of argumentation approach on students' learning and understanding the concepts in science classes. For example, Demirbağ and Günel (2014) investigated the effect of integrating the Argument-Based Science Inquiry approach on college students' achievement, and their argumentation and writing skills. The results of the study revealed that the scores of the students taught by argumentbased inquiry were higher than the ones in the comparison group. Cross and others (2008) searched for the effect of argumentation approach on some variables in a high school biology classroom. The results of the study displayed that the argumentation approachaffectedstudents' learning and achievement in science positively. Çetin (2014) stated that argumentation-based instruction increased students' understanding of the reaction-rate related concepts in chemistry. Aydeniz, Pabuççu, Çetin, and Kaya (2012) found that argumentation approach increased students' understanding in the subject of properties and behaviors of gases. Kaya (2013) aimed to investigate the effect of argumentative practices on pre-service teachers' conceptual understanding of chemical equilibrium. The findings of the study revealed that the experimental group taught by argumentation-based instruction scored better than the control group taught by traditional instruction. Similarly, Sampson and Walker (2012) and Berland and McNeill (2010) stated that students' learning increased with the help of argumentation-based instruction when compared to the students in traditional teacher-centered classes. Zohar and Nemet (2002) stated the importance of the argumentation process while learning scientific concepts meaningfully. The findings of this study and the findings of the other studies given as example showed that argumentation based science teaching approach facilities the students' understanding of the concepts and increases their learning. So, it can be stated that argumentation based science learning is an effective approach to science learning. 
In this study, the teacher directed the students investigate the concepts of acid-base with the authentic scenarios which were based on the daily lives of the students. The following stage was carried out in the laboratory. The students completed the stages in the argumentation process by conducting experiments. Students have played an active role in every stage of the learning activities. Since the daily life connections were established in the activities and the students researched and reached the information by themselves, the learning process meaningful became meaningful. That was the reason why the experimental group students which were taught through the argumentation-based science teaching approach had higher academic achievement compared to the control group students who were taught the same subject through didactic teaching approach. Experimental group students thought and acted like a scientist in the argumentation process, and that helped them to increase their learning of the concepts.

The findings of the study displayed that at the end of the application process there was no significant difference between post-testSPST scores of the experimental and control groups, but when pre and post-testSPST scores of the experimental group students were compared there was a significant increase in favor of post-test. This finding revealed that argumentation based science teaching approach had a positive effect on the experimental group students' scientific process skills. Similarly, Gultepe and Kılıç (2014) found that scientific argumentation approach had a significant effect on students' scientific process skills in chemistry class. This result suggested that argumentation based science teaching approach is one of the instructional approaches which facilities the development of students' scientific process skills. It is very important for students to develop their scientific process skills, to think like a scientist, to get better understanding related to the scientific concepts and to increase their interest in science, and to educate students as science literate. The main purpose of the national science education program is to educate all individuals as science literate (MEB, 2018). Science literate individuals are individuals who have scientific process skills, are trying to solve problems in their environment, produce solutions for problems by working alone or working collaboratively, and have creative and analytical thinking skills. According to Schafersman (1991), scientific process skills are the basis of scientific literacy. With these skills, students can learn science easier and feel responsible for their learning, be aware of the connections between knowledge and their daily lives. In several researchers, the findings displayed the positive effect of these skills while learning science (Chang \& Weng, 2000; Flores, 2000; Turpin \& Cage, 2004).

In argumentation based science learning, students understand the connection between the claim and the evidence and that helps to develop scientific process skills (Erduran, Simon, \& Osborne, 2004). In a scientific process, it is necessary to look at the events from different perspectives and to put forward different solutions. In the context of the study, in the laboratory environment, instead of conducting cookbook style experiments, students experienced an experimental process that they managed by themselves. In these experiments, they needed to make reasoning and put forward alternative solutions. Students conducted experiments and collected data to find an answer to a research question. They also put forward their arguments and warrants and backings for their arguments. During the argumentation process, students learn how to think (Driver, Newton, \& Osborne, 2000). The authentic scenarios used in the application process were related to the daily life of the students. The open-ended questions in the worksheets were posed following the scenarios, and these questions fostered students to think and search. Students had to use a wide range of skills in this application process. The argumentation-based science teaching approach is an approach that improves students' reasoning and supports their cognitive learning (Yore, 2000). In this approach, students often use the elements of the language such as reading and writing (Keys et al., 1999) and therefore it is an effective method in the development of scientific literacy (Burke et al., 2005).

The findings of the study displayed that, argumentation based science teaching approach had no significant effect on students' attitudes towards science class. Since the application period is only five weeks, it is thought that there was no significant change in students' attitudes towards the course. Individuals' attitudes towards any subject occur as a result of a wide range of experiences throughout their lives and over a long period. Therefore, it is not possible to change attitudes in a short period.

\section{CONCLUSION AND SUGGESTIONS}

When the application process is taken into consideration in general, it can be seen that the students had difficulty in forming arguments at first but that the arguments they formed during the ABSLapplication have developed. During the application, it has been observed by the teacher in charge that the students' willingness to participate in the application and interest in the lesson has increased. The sample group students who participated in the study had difficulties in forming arguments at first,and this shows that lessons which are based on memorization and taught traditionally since today make it difficult for the students to think like scientists. However, it has been seen that the ABSL approach develops the student' skill of forming arguments during the application, increases their willingness to access scientific information, guides them to think like scientists and increases their academic success. In this study, the students' organizing their arguments in the later stages of the application, steering towards scientific concepts, need to find sources for their arguments have increased the quality of the arguments and their tendency towards scientific knowledge.

In this study, the ABSL approach has been applied to those students who had a lower presence record in the lessons. Despite this, the application carried out has positively affected the success of the students. Also, the development of the students' skill of forming arguments and the increase in their participation in laboratory activities have also resulted in the students' learning science lessons by liking them. The ABSL approach is a very effective approach regarding removing the idea from people's minds that information should be readily 
taken from teachers and books to increase students' academic success.

When we take a look at Ministry of Education's (2018) science curriculum, one of the competencies which are desired for the students to acquire is "Learning How to Learn" (MEB, 2018). Within the program, this competence is defined as follows: "It is the competence which involves going after learning and being persistent about learning, for the individual to be able to organize his action of learning as to involve managing time and information management individually or within a group. This competency involves the individual's being aware of learning needs and processes by recognizing the existing opportunities and his skills of being able to overcome difficulties for a successful learning process. Acquiring new information and skills, developing these and adapting them to oneself also means looking for guidance support and making use of it. Learning how to learn prompts learners regarding using and applying information and skills in various contexts such as home, workplace, educational and training environments making use of previous learning and life experiences." In all of the activities carried out with the argumentation-based science teaching approach within the scope of the study, it was possible to have the students actively participate in the process, and the students have assumed their learning responsibilities to make progress in the process. In activities which were carried out, the teacher has acted as a guide. The students have done research to reach new information. They have done experiments using their skills and have formed arguments-data-reasons-supports and refutations in line with these skills. In the light of the activities which were carriedout and the obtained results, it has been seen that the argumentation-based science teaching approach is a suitable approach regarding the competence of 'learning how to learn' which the national science education aims at developing.

When the special goals of the national science lesson program are analyzed, some of the following items are noteworthy:

2. In the process of exploring nature and understanding the relationship between humans-environment, adopting skills involving scientific process and the scientific research approach and formulating solutions for the problems arising in this area.

4. Making it possible to assume responsibilities related to daily life problems and using information related to science in solving these problems, skills related to scientific process and other life skills.

6. Helping to understand how scientific information is created, the processes this created information goes through and how it is used in new studies.

7. Creating interest and curiosity related to nature and events which take place in its immediate surroundings (MEB, 2018).

When these goals are taken into consideration, it can be seen that argumentation-based science teaching approach allows students to establish daily life context with the concepts they are going to learn, to understand the place of acquired knowledge in solving daily life problems and to provide support in developing skills related to the scientific process. The findings of the study and the results of other literature studies stated above show that argumentation-based science teaching has a positive effect on learning scientific concepts.

In this study, the sample group which was applied the ABSL approach consists of 8 th-grade students who are receiving education in a village school. Since the school involved in the study is in a rural area and the students' teachers have changed frequently during the primary education process has caused a delay for the students in acquiring skills related to science lessons. Therefore, the students' presence in science lessons is insufficient. Basic skills related to science which are acquired in the middle-school level have made it difficult to develop attitudes related to science. Also, the students' reading, writing and argumentation skills being weak in primary school has made it difficult to carry out the ABSL approach. However, the ABSL application has increased the students' interest in science lessons. In this study, it has been seen that the students' willingness to participate in the ABSL process has increased and that the ABSL process has increased the academic success of the students. The findings obtained as a result of the study show that despite the difficulties experienced in the application process, the argumentation application is worth implementing. For the students to get used to the application process, they need to be given time, and the argumentation-based science teaching method should be made use of in teaching other subjects as well.

In line with the findings obtained in the study, the suggestions have been listed below:

- The ABSL approach has increased students' achievement in the subject of acids and bases but has been insufficient in developing an attitude. Therefore, the application process needs to be longer for the ABSL approach to be able to create positive effects on attitude. When the literature is reviewed, it is contradictory that some studies indicate that the ABSL approach increases the students" attitude towards science lessons. The ABSL approach can be applied in a long period, and the students' attitudes can be positively influenced by implementing the ABSL approach in another subject before science lessons. It takes a long time to develop an attitude towards a particular subject. During the study, with a single application period, ABSL did not cause any change in students' attitudes towards science. However, considering the positive contribution of the application on academic achievement, the use of ABSL in other subjects in the science class may affect students' attitudes positively.

- In the ABSL process, the students were accustomed to the traditional didactic approach and had difficulty adapting to a new method. In general, students were passive in the learning environment. But in ABSL approach they were encouraged to participate in the learning activities actively and were asked to write their arguments. The students had difficulties while writing their arguments since the approach was not familiar with them. Therefore, before the implementation, the process should be well planned, and the required information should be given to teachers and students at the beginning of the process. If possible, carrying out a simple application about the ABSL approach can facilitate teachers and students to understand the process in a speedier manner. 
- Planning the subject determined for the ABSL application in a manner which the students use or can use in their daily lives will increase the attribution of meaning by the students to the process.

- In the study process, the researchers prepared scenarios in line with the learning gains in the acids and bases unit. Then, the prepared scenarios were examined by experts, and the necessary arrangements were made. The preparation phase is a time-consuming process for the teacher, and the teacher should work hard. Since the preparation phase of the process is long and requires working hard, science teachers need to receive support on how to prepare and implement this contemporary approach in their classes.

- Making use of Authentic Case Studies and preparing case studies in a manner to encourage students for discussion will facilitate the applicability of the process through the ABSL approach.

- Since the ABSL approach requires the students to engage in having scientific discussions, the instructor should plan activities related to the students" expressing themselves and their communication skills.

- Although the ABSL approach is an approach which should be widely used in Turkey, in particular in science lessons, it is not being used widely. More place needs to be given to ABSL applications.

- It can be facilitated for the students to attribute meaning to the subject by preparing various materials in line with the individual characteristics of the study group students. Making the materials to be used more fun according to the grade levels will increase contribution to the study.

- Training can be provided about studies related to the ABSL approach and their results and in particular to science teachers and teacher candidates.

- There are many studies which reported positive effects of the argumentation process in science learning; therefore teachers should be trained about how to apply the argumentation process in their classes.

\section{REFERENCES}

Aikenhead, G. (2001). Integrating western and aboriginal sciences: Cross-cultural science teaching. Research in Science Teaching, 31, 337-355. https://doi.org/10.1023/ A:1013151709605

Akkus, R., Gunel, M., \& Hand, B. (2007). Comparing an inquiry-based approach known as the science writing heuristic to traditional science teaching practices: Are there differences? International Journal of Science Education, 1, 1-21.

Artdej, R., Ratanaroutai, T., Coll, R. K., \& Thongpanchang, T. (2010). Thai grade 11 students' alternative conceptions for acid-base chemistry. Research in Science \& Technological Education, 28(2), 167-183. https://doi.org/10.1080/ 02635141003748382
Aydeniz, M., Pabuççu, A., Çetin, P. S., \& Kaya, E. (2012). Argumentation and Students' conceptual understanding of properties and behaviors of gases. International Journal of Science and Mathematics Education, 10, 1303-1324. https://doi.org/10.1007/s10763-012-9336-1

Aydoğdu, B., Yıldız, E., Akpınar, E., \& Ergin, Ö. (2006). İlköğretim Öğrencilerinin Bilimsel Süreç Becerilerini Etkileyen Değişkenler. Eğitimde Çağdaş Yönelimler III Yapılandırmacılık Ve Eğitime Yansımaları Sempozyumu, 182-185.

Berland, L., \& McNeill, K. L. (2010). A learning progression for scientific argumentation: Understanding student work and designing supportive instructional contexts. Science Education, 94(5), 765-793. https://doi.org/10.1002/ sce.20402

Bradley. J. D., \& Mosimege, M. D. (1998). Misconceptions in acids \& bases: A comparative study of student teachers with different chemistry backgrounds. South African Journal of Chemistry, 51, 137-155.

Burke, K. A., Greenbowe, T. J., \& Hand, B. M. (2005). Excerpts from the process of using inquiry and the science writing heuristic (Doctoral Dissertation). Prepared for the Middle Atlantic Discovery Chemistry Program, MoravianCollege, Bethlehem.

Çetin, P. S. (2014). Explicit argumentation instruction to facilitate conceptual understanding and argumentation skills. Research in Science \& Technological Education, 32(1), 1-20. https://doi.org/10.1080/02635143.2013.850071

Çetingül, P. İ., \& Geban, Ö. (2005). Understanding of acid-Base concept by using conceptual change approach. Hacettepe University Journal of Education, 29, 69-74.

Chang, C., \& Weng, Y. (2000). Exploring interrelationship between problem-solving ability and science process skills of tenth-grade earth science students in Taiwan. Chinese Journal of Science Education, 8(1), 35-56.

Cross, D., Taasoobshirazi, G., Hendricks, S., \& Hickey, D., T. (2008). Argumentation: A strategy for improving achievement and revealing scientific identities. International Journal of Science Education, 30(6), 837-861. https://doi.org/10.1080/09500690701411567

Demirbağ, M., \& Günel, M. (2014). Integrating argumentbased science inquiry with modal representations: Impact on science achievement, argumentation, and writing skills. Educational Sciences: Theory \& Practice, 14(1), 386-391. https://doi.org/10.12738/estp.2014.1.1632

Demircioğlu, G., Ayas, A., \& Demicioğlu, H. (2005). Conceptual change achieved through a new teaching program on acids and bases. Chemistry Education Research and Practice, 6(1), 36-51. https://doi.org/10.1039/B4RP90003K

Demircioğlu, G., Özmen, H., \& Ayas, A. (2004). Some misconceptions encountered in chemistry: A research on acid and base. Educational Sciences: Theory \& Practice, 4(1), 73-80.

Driver, R. H., Asoko, J., Leach, E., Mortimer, P., \& Scott, P. (1994). Constructing scientific knowledge in the classroom. Educational Researcher, 23, 5-12. https://doi.org/10.3102/0013189X023007005 
Driver, R., Newton, P., \& Osborne, J. (2000). Establishing the norms of scientific argumentation in classrooms. Science Education, 84, 287-312. https://doi.org/10.1002/ (SICI)1098-237X(200005)84:3<287::AID-SCE1>3.0.CO;2-A

Duschl, R., \& Osborne, J. (2002). Supporting and promoting argumentation discourse. Studies in Science Education, 38, 39-72. https://doi.org/10.1080/03057260208560187

Erduran, S., Simon, S., \& Osborne, J. (2004). TAPping into Argumentation: Developments in the application of Toulmin's argument pattern for studying science discourse. Science Education, 88(6), 915-933. https://doi.org/10.1002/sce.20012

Flores, G. S. (2000). Teaching and assessing science process skills in physics: The "Bubbles" task. Science Activities, 37(1), 31-37. https://doi.org/10.1080/00368120009603556

Gultepe, N., \& Kılıç, Z. (2015). Effect of scientific argumentation on the development of scientific process skills in the context of teaching chemistry. International Journal of Environmental \& Science Education, 10(1), 111132. https://doi.org/10.1037/t51058-000

Jime'nez-Aleixandre, M.P., \& Pereiro-Munhoz, C. (2002). Knowledge producers or knowledge consumers? Argumentation and decision making about environmental management. International Journal of Science Education, 24, 1171-1190. https://doi.org/10.1080/09500690210134857

Jimenez-Aleixandre, M. P., Rodriguez, A. B., \& Duschl, R. A. (2000). "Doing the lesson" or "Doing science": Argument in high school genetics. Science Education, 84(6), 757-792. https://doi.org/10.1002/1098-237X(200011)84:6<757::AID -SCE5>3.0.CO;2-F

Kala, N., Yaman, F., \& Ayas, A. (2013). The effectiveness of predict-observe-explain technique in probing students' understanding about acid-base chemistry: A case forthe concepts of $\mathrm{pH}, \mathrm{pOH}$, and strenght. International Journal of Science and Mathematics Education, 11, 555-574. https://doi.org/10.1007/s10763-012-9354-z

Karadeniz Bayrak, B. (2013). Using two-tier test to identify primary students' conceptual understanding and alternative conceptions in acid base. Mevlana International Journal of Education (MIJE), 3(2), 19-26. https://doi.org/10.13054/mije.13.21.3.2

Karpudewan, M., Roth, W., M., \& Sinniah, D. (2016). The role of green chemistry activities in fostering secondary school students' understanding of acid-base concepts and argumentation skills. Chemistry Education Research and Practice, 17, 893-901. https://doi.org/10.1039/C6RP00079G

Kaya, E. (2013) Argumentation practices in classroom: Preservice teachers' conceptual understanding of chemical equilibrium. International Journal of Science Education, 35(7), 1139-1158. https://doi.org/10.1080/09500693.2013. 770935

Kelly, G. J., Drucker, S., \& Chen, C. (1998). Students' reasoning about electricity: Combining performance assessments with argumentation analysis. International Journal of Science Education, 20, 849-871. https://doi.org/10.1080/ 0950069980200707
Keys, C. W. (2000). Investigating the thinking processes of eighth grade writers during the composition of a scientific laboratory report. Journal of Research in ScienceTeaching, 37(7), 676-690. https://doi.org/10.1002/1098-2736(200009 )37:7<676::AID-TEA4>3.0.CO;2-6

Keys, C. W., Hand, B., Prain, V., Collins, S. 1999. Using the science writing heuristic as a tool for learning from laboratory investigations in secondary science. Journal of Research in Science Teaching, 36(10),1065-1084. https://doi. org/10.1002/(SICI)1098-2736(199912)36:10<1065::AID-TE $\mathrm{A} 2>3.0 . \mathrm{CO} ; 2-\mathrm{I}$

Kılınç, A. (2014). İşbirlikli Öğrenme Yönteminin (Jigsaw Tekniği) Asitler ve Bazlar Konusunda Öğrenci Başarısına Etkisi ve Öğrenci Görüşleri (Masters Thesis). Gazi Üniversitesi Eğitim Bilimleri Enstitüsü. Ankara.

Kousathana, M., Demerouti, M., \& Tsaparlis, G. (2005). Instructional misconceptions in ccid-base equilibria: An analysis from a history and philosophy of science perspective. Science \& Education, 14, 173-193. https://doi.org/10.1007/s11191-005-5719-9

Lawson, A. E. (2003). The nature and development of hypothetico-predictive argumentation with implications for science teaching. International Journal of Science Education, 25, 1387-1408. https://doi.org/10.1080/ 0950069032000052117

Leach, J. (1999). Students' understanding of the co-ordination of theory and evidence in science. International Journal of Science Education, 21, 789-806. https://doi.org/10.1080/ 095006999290291

Mason, L. (1996). An analysis of children's construction of new knowledge through their use of reasoning and arguing in classroom discussions. Qualitative Studies in Education, 9, 411-433. https://doi.org/10.1080/0951839960090404

MEB (2018). Fen Bilimleri Dersi Öğretim Programı. Retrieved on 27 November 2018 from http://mufredat.meb.gov.tr/ Dosyalar/201812312311937-FEN\%20BİLIMLERİ\%20ÖĞRE TIM\%20PROGRAMI2018.pdf

Meriç G. (2014). Fen ve Teknoloji Dersinde Kavram Karikatürlerinin Öğrencilerin Kavramsal Anlama, Motivasyon ve Tutum Düzeyleri Üzerine Etkisi (Masters Thesis). Celal Bayar Üniversitesi Fen Bilimleri Enstitüsü. Manisa.

Newton, P., Driver, R., \& Osborne, J. (1999). The place of argumentation in the pedagogy of school science. International Journal of Science Education, 21, 553-576. https://doi.org/10.1080/095006999290570

Nussbaum, M., \& Sinatra, G. (2003). Argument and conceptual engagement. Contemporary Educational Psychology, 28, 384-395. https://doi.org/10.1016/S0361-476X(02)00038-3

Osborne, J., Erduran, S., \& Simon, S. (2004). Enhancing the quality of argumentation in school science. Journal of Research in Science Teaching, 41(10), 994-1020. https://doi.org/10.1002/tea.20035

Patronis, T., Potari, D., \& Spiliotopoulou, V. (1999). Students' argumentation in decision-making on a socio-scientific issue: Implications for teaching. International Journal of Science Education, 21(7), 745-754. https://doi.org/10.1080/ 095006999290408 
Ross. B. \& Munby. H. (1991). Concept mapping and misconceptions: A study of high school students' understanding of acids \& bases. International Journal of Science Education, 13, 11-24. https://doi.org/10.1080/ 0950069910130102

Sampson, V., \& Walker, J., P. (2012). Argument-driven inquiry as a way to help undergraduate students write to learn by learning to write in chemistry. International Journal of Science Education, 34(10), 1443-1485. https://doi.org/ 10.1080/09500693.2012.667581

Şaşmaz-Ören F., Tezcan R., 2009. İlköğretim 7. Sınıf Fen Bilgisi Dersinde Öğrenme Halkası Yaklaşımının Öğrencilerin Tutumları Üzerine Etkisi. Elementary Education Online, 8(1), 103-118.

Schafersman, S. D. (1991). An introduction to critical thinking. Retrieved from http://smartcollegeplanning.org/wpcontent/uploads/2010/03/Critical-Thinking.pdf

Schmidt, H. J. (1995). Applying the concept of conjugation to the Bronsted theory of acid-base reactions by senior high school students from Germany. International Journal of Science Education, 17, 733-742. https://doi.org/10.1080/ 0950069950170605

Schwarz, B., Neumann, Y., Gil, J., \& Ilya, M. (2003). Construction of collective and individual knowledge in argumentative activity. Journal of the Learning Sciences, 12, 219-256. https://doi.org/10.1207/S15327809JLS1202_3

Sheppard, K. (2006). High school students' understanding of titrations and related acid-base phenomena. Chemistry Education: Research and Practice, 7, 32-45. https://doi.org/10.1039/B5RP90014J
Suppe, F. (1998). The structure of a scientific paper. Philosophy of Science, 65, 381-405. https://doi.org/10.1086/392651

Tarhan, L., \& Acar Sesen, B. (2012). Jigsaw cooperative learning: Acid-base theories. Chemistry Education Research and Practice, 13, 307-313. https://doi.org/10.1039/ C2RP90004A

Turpin, T., \& Cage, B. N. (2004). The effects of an integrated activity-based science curriculum on student achievement, science process skills and science attitudes. Electronic Journal of Literacy Through Science, 3, 1-15.

Tuysuz, C., Demirel, O., E., \& Yildirim, B. (2013). Investigating the effects of argumentation, problem, and laboratorybased instruction approach on pre-service teachers' achievement concerning the concept of "acid and base". Procedia - Social and Behavioral Sciences, 93, 1376-1381. https://doi.org/10.1016/j.sbspro.2013.10.047

Von Aufschnaiter, C., Erduran, S., Osborne, J., \& Simon, S. (2008). Arguing to Learn and Learning to Argue: Case Studies of How Students' Argumentation Relates to Their Scientific Knowledge Claudia von Aufschnaiter. Journal of Research in Science Teaching, 45(1), 101-131. https://doi.org/10.1002/tea.20213

Yore, D. L. (2000). Enhancing science literacy for all students with embed reading instruction and writing to learn activities. Journal of Deaf Studies and Deaf Education, 5(1), 105-122. https://doi.org/10.1093/deafed/5.1.105

Zohar, A., \& Nemet, F. (2002). Fostering students' knowledge and argumentation skills through dilemmas in human genetics. Journal of research in science teaching, 39(1), 3562. https://doi.org/10.1002/tea.10008 


\section{APPENDIX 1}

\section{Case Studies on the Subject of Acids and Bases}

\section{Section 1}

Mustafa is an 8th-grade primary school student. A new school was built in his village. He was quite happy about the school. However, after school started, he saw that the science laboratory materials in his school were very insufficient. He felt upset about this because he liked the Science and Technology lesson. One day, he was very happy to see that his Science and Technology teacher came to the school with laboratory materials. His Science and Technology teacher chose Mustafa and a few of his friends to organize the laboratory. There were new materials in the laboratory Mustafa did not know about or saw for the first time. Mustafa and his friends constantly asked questionsabout the materials. Their teacher tried to explain the names and some characteristics of the materials with a few simple words. Then, it was time to organize the chemical substances. While Mustafa was organizing these chemical substances, his teacher told him to be careful,and Mustafa was even more interested in these substances. Mustafa was curious as to what concepts such as acid and hydroxide wrote on some of the chemicals were and asked his teacher questions about these. His teacher briefly answered his question with the lemon and soap example. His teacher told him that food or materials he uses in his home every daycare either acids or bases. Since the pH scale and the litmus paper used in the laboratory are used to distinguish between acids and bases, his teacher also briefly explained what these were. However, his teacher's answers did not satisfy him,and he was even more curious. Mustafa thought that there might be a difference in the chemistry of soap and lemon. He thought that there might be other ways of distinguishing between the concepts of acids and bases and decided to do some research about this.

The organization of the laboratory was completed. Mustafa shared the questions on his mind after school with his friends who organized the laboratory with him. However, they did not know anything about this subject. Mustafa who lived in a village decided to read the labels of the materials he had in his home. He wondered whether most of the materials used in his home displayed acidic or basic qualities. When he got home, there was a sack of fertilizer in frontof his door. On the label of the fertilizer sack, there were the concepts of Phosphoric acid and nitric acid. When Mustafa read the label of the soft soap they used at home, he saw that it said potassium hydroxide on it under the contents part and when he checked the labels of the normal soap, the labels said sodium hydroxide. He saw on the label of the cement sack at the construction right next to their house that it said calcium hydroxide. He realized that some medicine labels said ammonia and some detergents' labels said sodium carbonate. Mustafa noted each of these, and he became even more curious and confused about the subject.

\section{APPENDIX 2}

\section{Worksheet 1}

1) Which senses did Mustafa use when distinguishing between acids-bases? How did these materials affect his senses?

2) As a result of his researches, which conclusion did Mustafa reach about which ions exit in the chemistry of acids and bases?

3) As a result of his researches, which conclusion did Mustafa reach about what kind of material the pH scale is when his teacher defined it as the $\mathrm{pH}$ scale?

4) Using litmus paper, state what kinds of changes acids and bases cause on litmus paper. What other materials are there like litmus paper which can be used to distinguish between acids and bases? 